\title{
ARCHAEOLOGICAL CERAMICS IN LITHUANIA: PRIMARY PROCESSING
}

\section{GINTAUTAS ZABIELA}

\begin{abstract}
The article discusses ceramic fragments and their primary processing at the report level of archaeological explorations. Archaeologists in Lithuania still employ two methods in the description of fragments, text and tables, of which the latter holds most promise. Their wider employment is restricted by the absence of general standards. Out of at least 36 attributes that characterise ceramic fragments, five main ones can be distinguished (ceramic group, type of utensil fragment, diameter, number, weight), and they should be obligatory in every report on archaeological research.
\end{abstract}

Key words: archaeological ceramics, potsherds, attributes of ceramic fragments, ceramics description tables

Ceramic fragments are the most numerous archaeological finds from periods that used ceramics. Most finds from the pre-ceramic period are flint articles. However, after the arrival of ceramics, they lost their status as the most common finds. The abundance of ceramics can be explained by three main causes. Firstly, ceramic articles are very rarely found intact. By far the largest part of them consists of fragments, which can later serve as material for the partial or full reconstruction of former articles. Secondly, ceramic articles are of different sizes, and fragments of them can amount to hundreds (depending on their fragility and the conditions of their further existence). And thirdly, they can be scattered around large areas, thus preventing their combination into a single unity. This results in an artificial abundance of them, enhanced by two other factors. Ceramic articles are not reprocessed, although under specific conditions the clay mass serving as the basis for a ceramic article (not necessarily a utensil) can turn back into clay. However, new ceramic articles are manufactured from new raw material, whereas different reprocessed old ceramic articles can be employed only as additives, or even used for totally different purposes. Ceramics (utensils) are a very important part of human daily life. At the same time, they are not very durable, and very often become useless. Thus, ceramics have become a basic indicator, the main archaeological object in our understanding of human life in the past. In this way, the unity of these three factors forms the most numerous group of archaeological finds in archaeological material.

This article ${ }^{1}$ makes no attempt to offer a profound review of ceramics-related studies. The materials in this

\footnotetext{
1 It is based on the report given at the conference 'Ceramics: Investigations in Lithuania and Prospects' on 12-13 November 2009. Klaipeda University, Klaipèda.
}

sphere of research are so different and so plentiful that they could serve as a subject for at least one book. Not being a ceramicist or an expert in old crafts, the author is not qualified to make a complete analysis of these spheres, so there will be no attempt to do so in this article. However, experience gained on field trips and discovered and inevitably preliminarily processed ceramics allow for the discussion of this aspect in detail, the more so because there have been no generalising studies on the subject until now. All ceramics discovered during archaeological explorations in Lithuania are the subject of the research, paying particular attention to the development of primary processing, distinguishing essential and secondary aspects, and showing the contribution of Lithuanian researchers to primary studies of ceramics. The article restricts itself to Lithuania, as nowadays almost every country sticks to its own particularity in archaeological explorations, and a superficial and selective comparison of the above contribution would be illustrative at best. Attention in the article is focused on fragments of ceramic utensils, avoiding the review of less problematic studies in intact (from an archaeological point of view) ceramic utensils. The contribution of European researchers in this sphere is huge, and a review of the contribution of national archaeologists alone would be insufficient. The article also discusses the aspect of primary processing of fragments for reports.

According to recent data, ceramics appeared in the area of modern Lithuania around 5500 to $5300 \mathrm{BC}$ (in the Katra settlement in the Varena region) (Girininkas 2009 , p.127). Since then, up to the 19th century, ceramic utensils dominated in daily life, and only in the 20th century were they pushed out by articles made of metal, plastic, glass or other materials. New archaeologically explored and described ceramics come from 
the second half of the 19th century (Klaipedos 2010, catalogue No 385). Therefore, ceramic fragments remain the main find on the sites of 7,000-year-old ancient settlements. Out of 5,000 explored sites, ceramics were found in more than 4,000 of them, and the total number of discovered fragments could hardly be evaluated, as they make up over a million (Zabiela 2010, p.27). The numbers of ceramic fragments in various explored objects are very different. They vary from one (Renavas) (Valatka 1974, p.14) to 100,000 (Nida) (Rimantienè 1989, p.87). However, these are extreme figures. Usually they vary from tens to several thousand (according to the registers of research reports). Still, this is a relatively large number of articles, with proper characterisation, that each archaeologist comes across. Naturally, the increase in their numbers leads to an increase in the problem, so a smaller number of fragments could be better characterised and defined.

The characterisation of discovered ceramics is exceptionally uneven, which makes further studies of ceramics problematic. This is the main reason why there are still so few studies of the most numerous type of archaeological find. Attempts have been made to write single articles about ceramics; ${ }^{2}$ however, general studies in Lithuania are still exceptionally rare. ${ }^{3}$ A rchaeology has developed into a specific pattern in the publication of material and introducing broader generalisations, classifying them on the basis of local groups and making no parallels with other similar groups. Consequently, ceramics remain purely an illustrative annex, pointing to the fact that authors have not forgotten it, are working on it, but have nothing to say. The processing of ceramics from the Birute Hill hill-fort in Palanga by Vladas Žulkus is an exception (Žulkus 1997; 20074). However, it is also very professionally accomplished work on the basis of one single object, with 928 fragments analysed in particular (Žulkus 2007, p.234ff).

Primary unprocessed ceramics, introduced in research reports, prevent any wider generalisation. Any researcher can give space and time to the characterisation of ceramics in a report. However, due to the different methods of characterisation employed, every new researcher has to either deal directly in the depositories of museums, or excavate himself. Is the situation so desperate? Will new generations of researchers have to spend time on falsified activities? In order to realise this and start changing it, it is necessary to review the

\footnotetext{
${ }^{2}$ For this see the appendix-bibliography on Lithuanian archaeological ceramics (edited by Tautavičius 2000) with further supplements. Studies in which ceramics are described (sometimes even very exhaustively) together with other archaeological material are not included in it.

3 The catalogue only can be indicated: Klaipedos 2010.

4 The study of 1997, supplemented with an English version.
}

actual situation in the processing of ceramic fragments, and to find out how it has come about.

The first Lithuanian researchers did not pay proper attention to ceramics for a long period of time. For a long time, most of their attention was focused on the excavation of burial grounds, and also on settlements around hill-forts. In the 1840s, Franciszek Wilczyński mentioned fragments found around Narkūnai hill-fort (near Utena, in eastern Lithuania) (Wilczyński 1836, p.559). At the end of the 19th century, as archaeology was developing, attention to ceramics increased. From then, more detailed descriptions of ceramic fragments appeared. Juliusz Döring in 1882 mentions a grey, slightly encaustic, fragment of a pot, with additives of powdered granite, discovered in the Ažuolpamūšè hill-fort (near Pasvalys, in northern Lithuania) (Döring 1882, p.41). Juozas Žiogas, discussing ceramics found around Imbare hill-fort (near Kretinga, western Lithuania), describes the colour and peculiarities of manufacture, and tries to attribute fragments to different types of utensils (Žiogas 1900, p.42). Ludwik Krzywicki intended to make a special study about ceramics (Krzywicki 1917, p.39); however, he could not. Instructions from the Vilnius Archaeological Committee, which operated during the period from 1911 to 1914, also insisted on paying particular attention to fragments of glass, clay and porcelain utensils (Kulikauskas, Luchtanas 1980, p.100). However, the reality was different, and little attention was paid to them (p.107).

Interest in ceramic fragments in the interwar period was slight. In 1924, Petras Tarasenka acknowledged that 'clay utensils, particularly pots, have turned into fragments, which are valued little by society and even researchers. Occasionally, several fragments find their way into museums, but most vanish, even though they are important to research' (Tarasenka 1924, p.85). Almost nothing is available about ceramics in 'Data from the Latest Prehistoric Studies' by Jonas Puzinas, which is the most important archaeological work from that period (Puzinas 1938, pp.293, 296). Włodzimierz Hołubowicz, working in the Vilnius region, paid more attention to ceramics, as he specialised in the area. ${ }^{5}$

The situation with the specification and characterisation of ceramic fragments in Lithuania started changing in the 1950s. In the first extensive explorations of Nemenčinè hill-fort (near Vilnius, in eastern Lithuania) in 1952, ceramics were already classified in groups, describing them in the following way: '348-376. Fragments of manually modelled thin-sided or thick-sided pots, some of them profiled, with sand additive and with line-surface' (Kulikauskas, Kulikauskienè 1956,

5 He published a book in the postwar period: Hołubowicz 1950.

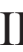

ARCHAEOLOGICAL CERAMICS 
p.6). ${ }^{6}$ From then on, ceramics from hill-forts and settlements were given full descriptions, although in the exploration of old towns and castles (where ceramics are abundant) such descriptions were still lacking for another decade. Even in broad explorations of the Vilnius castles area from 1955 to 1961 , ceramics are described (in a very general way) only as a group of finds (Tautavičius 1956, p.52ff). Finds discovered in 1959 around the present-day National Museum of Lithuania were not collected, and ceramics itself were characterised in general (Legaitè-Skardžiuvienè 1967, p.4). All the attention of archaeologists was focused on layers and structures. In the 1960s, the exploration and analysis of archaeological material in Kaunas was 'implemented in a disorderly way’ (Žalnierius et al. 1984, p.5). ${ }^{7}$

The description of ceramics in Lithuanian archaeological studies finally established itself in the 1970s. For example, in 1976, ceramics from K. Giedrio St 8 (now šv. Ignoto St) in Vilnius were described together with other finds, specifying their colour, thickness, additives and glaze (Bešènienè 1976, pp.56-94). A similar form of description was employed in Kaunas. In 1975, ceramics from Rotušès Square were also described, together with other finds, specifying their colour, size, thickness, shape and glaze (Žalnierius 1975, p.7ff).

At the beginning of the $1990 \mathrm{~s}$, the description of ceramics by means of tables also began. Signs of this could be seen in the first half of the 1980s, when descriptions were already placed in tables, specifying only the elements of archaeological fixation (Markelevičius 1973, p.9ff). The first tables come from reports from the Monument Conservation Institute. This was stimulated by extensive explorations of the area around K. Giedrio St 8 in 1983. An area of about 3,000 square metres was explored (Ušinskas 1984), which resulted in the discovery of over 13,000 ceramic fragments, and the necessity to formalise their description. A table with 104 columns for descriptions was developed (Ušinskas 1983) (Fig. 1). It was universal, wide, and included possibilities for electronic processing (formalised coded assistance) (Vaitkiavichius et al. 1985). This factor explains the large number of columns.

At the end of the 1980s, the archaeologist V. Žulkus, from the Klaipeda branch of the above institute, developed a local method for the description of archaeological material, based on formalised shapes of rims and utensils (Žulkus 1981a; 1981b) (Fig. 2). In this case, the characterisation of rims (then called brims) is most significant for us. 'Shapes of rims are characterised on

\footnotetext{
6 The list itself appeared later, in 1955-1956.

7 The report itself was completed in 1984.
}

the basis of a semantic principle: the graphic shape of the symbol employed corresponds directly to the shape of the rims. Letters from the Latin alphabet and derivatives of them are symbols denoting the different types: e, B, I, D, R, I, r, and so on (this notation for ceramics is already employed in planning reports on archaeological exploration)' (Žulkus 1981b, p.38). This table had 94 columns (Fig. 3).

Recent reports on archaeological exploration employ both methods of description (text and tables). The textual (descriptive) characterisation of fragments is primary, informal and has changed very little with the passage of time. The material from Narkūnai hillfort, explored between 1976 and 1978, and containing thousands of fragments, was described in this way. ${ }^{8}$ It was characterised in the following way: 'Six fragments with a brushed surface, one of them belongs to the base of a pot. Two other fragments come from its rims. One of the rims is decorated with dimples, a rim of another fragment is decorated with a pinched-impressed pattern, external and internal parts of the fragment are pinched-impressed horizontally' (Kulikauskienè 1977, p.250). This description is very similar to the description of ceramics from Nemenčine hill-fort quoted above and written two decades earlier. Similar examples from recent practice could also be offered. Only the characterisation in them of the described ceramic fragments is different.

The table is a more progressive form of description. It is standardised, more spread out, concentrating information, and even saving space for reports. However, after an analysis of the forms employed by different researchers, it becomes evident that their failing is in the use of different attributes in the characterisation of ceramic fragments. Therefore, on a large scale, tables lose the significance of a standardised description. Presumably, reports on recent archaeological explorations contain tables with purely statistical descriptions of ceramics.

One solution to the problems related to the processing of ceramic material was also suggested earlier by the author of this article (Zabiela 1987), proposing to replace inventories of them with tables of two types, quantitative bulletins and qualitative descriptions. A sampling for quantitative tables was offered: to leave out rims under one centimetre by one centimetre, ornamented or rare types of ceramics, side and base fragments under two by two centimetres (Zabiela 1987, p.32). The description of ceramic fragments in

\footnotetext{
8 Even in publications about the exploration of the lower layer (Volkaite-Kulikauskienè 1986), it is mentioned that ceramics made up 'a very large' group of finds (p.37).
} 


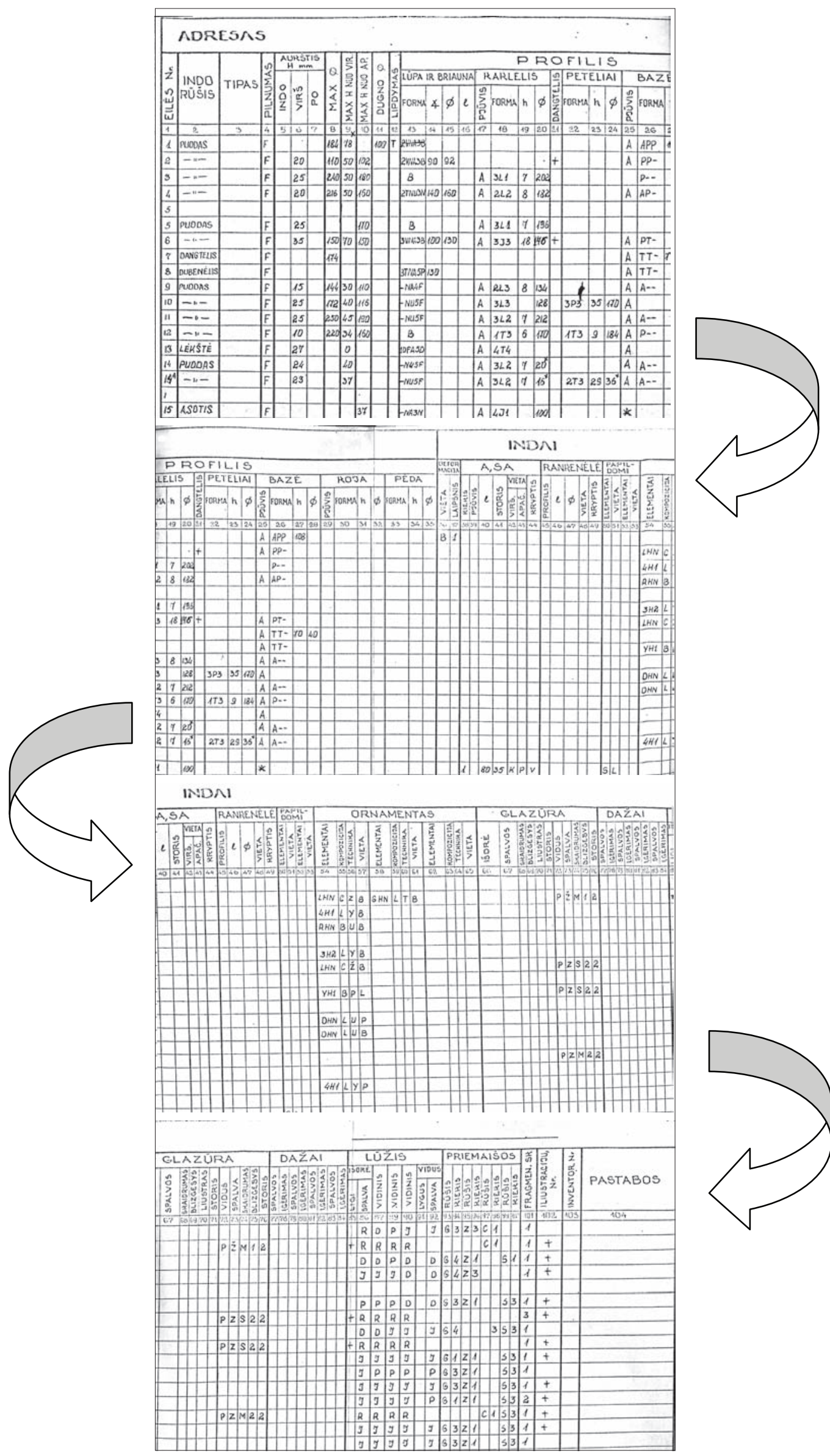

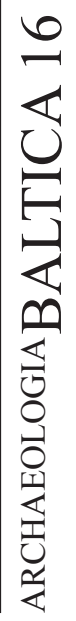

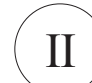

ARCHAEO-

LOGICAL CERAMICS

Fig. 1. The table employed in the description of ceramics at the Monument Conservation Institute (after Ušinskas 1984). 


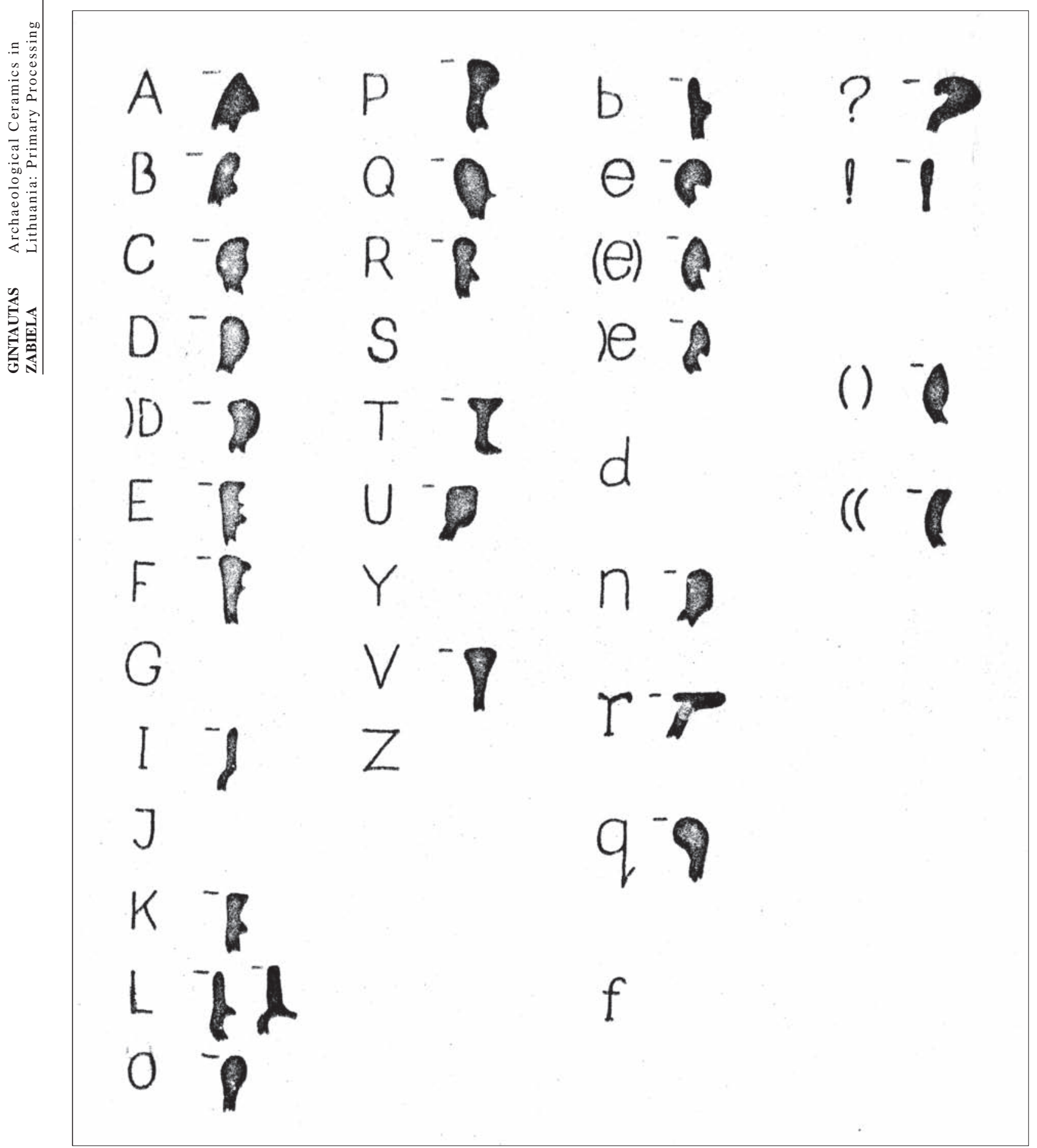

Fig. 2. V. Žulkus' table for marking ceramic rims (after Žulkus 1981c, p.127). 


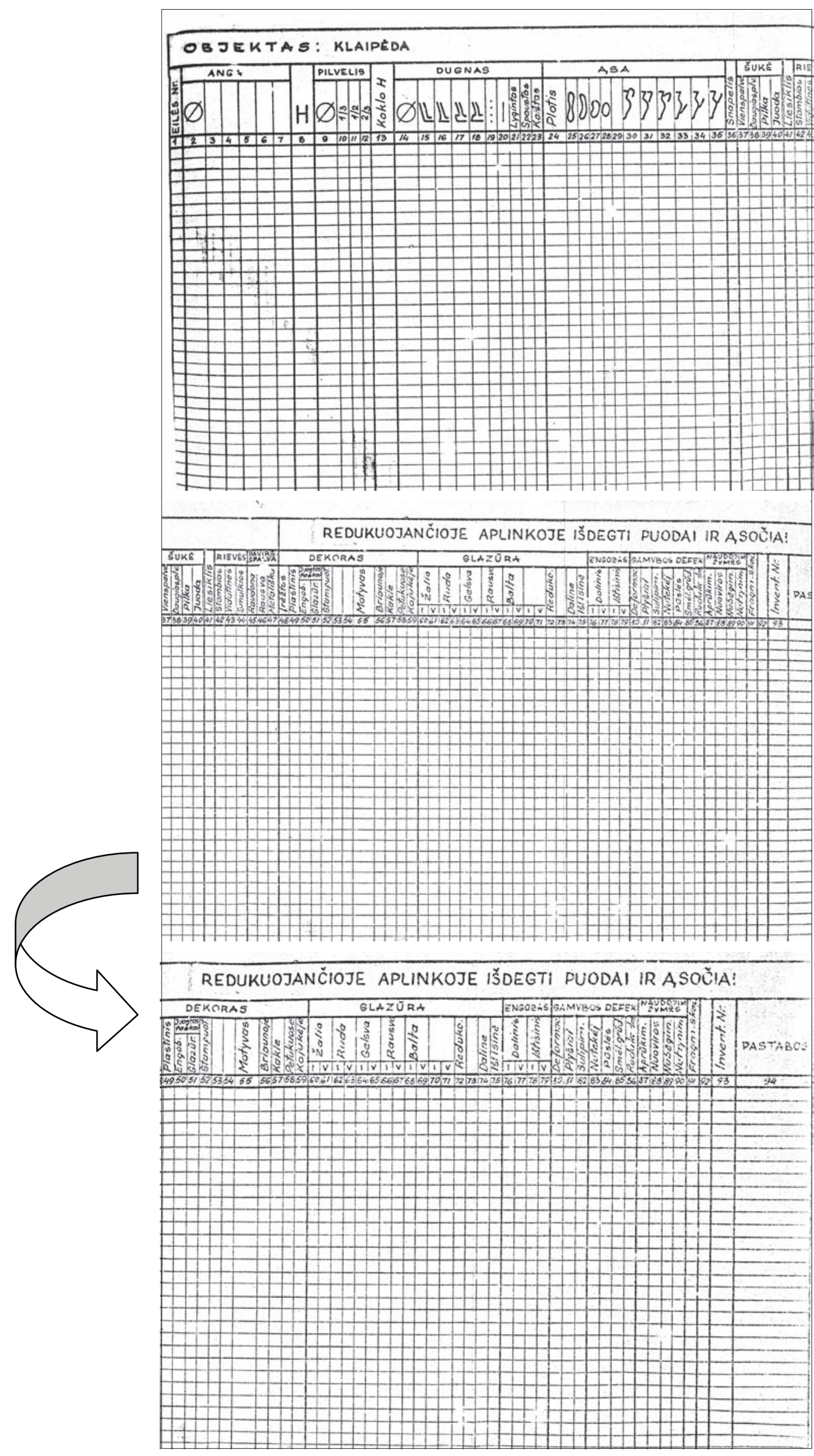

Fig. 3. V. Žulkus' table for the description of ceramics (after Žulkus 1981a, p.16, Fig. 4). 


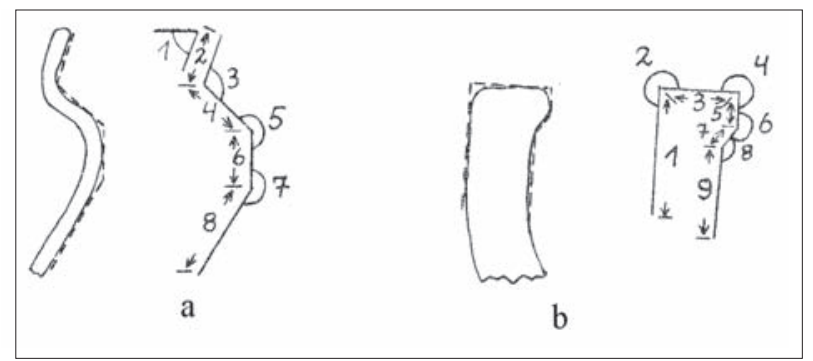

Fig. 4. The ceramic brim characterisation scheme (after Zabiela 1987, p.34, Fig. 1).

qualitative tables should contain their basic attributes, the physical parameters of which are characterised by numbers and words (Zabiela 1987, p.33). The shape of the rims should be described in a formalised way: the sequence of length and the angles between them (Zabiela 1987, p.34, Fig.1) (Fig. 4), which failed to naturalise in archaeological literature due to the comparatively long and subjective working process. The weight of fragments was introduced in the above tables only in the last decade of the 20th century.

These tables were treated as a step forward. However, their data is employed very little in further summaries and generalisations. The variety of these tables could be blamed for this failure. It is possible to maintain that each researcher introduced his own standards, on the basis of which only specific columns can be treated as interdependent. An analysis of different descriptive tables allows us to assume that researchers are not sure what they expect from a ceramic fragment. Some emphasise the external shape and physical parameters, others focus on the technique of manufacture or chronology and cultural dependence; 36 attributes of fragments are chosen from different tables. They are: colour (external, internal, mass), size, thickness (minimum, maximum), shape (rim, base), additives (type, size, numbers), group, glaze (colour, site, clarity, polish, thickness), colouring, type (utensil or part of one, technical, cultural), number, weight, ornament (technique, type, dimensions, number of elements, site), diameter, deformations, throwing flutes, firing, shape, signs and symbols, and signs of usage. Based on their narrow distribution and the addition of columns for registered archaeological finds, the above-mentioned descriptive table with 104 columns was completed. Compiling such tables is a very laborious process. In order to compile one properly and correctly, a set of instructions covering nine pages was developed. The very placing of such a big table in a report and its further employment became problematic, and resulted in the expansion of the report itself. Attempts were made to rationalise this process, providing each fragment in pre-computer times with a push-card (Fig. 5). How- ever, this was only useful in the search for necessary information, but not in its introduction and safety. This method was very soon abandoned. The emergence of computers and special programmes solved problems relating to the search for information and its systematisation. However, the introduction of information and safety-related problems persisted. Problems related to completeness in filling in the columns of such a big table also persisted, as it is impossible to trace a fragment which could fill all of the 36 above-mentioned columns, let alone exhaustive tables. An increase in columns leads to a number of blank squares. Essential and inessential attributes of fragments become a major problem. Their specification is a rather complicated problem, as it is necessary to pay attention to several factors: the huge variety of ceramics, the many unsuccessful attempts at a unified description, the subjective character of physical criteria in the characterisation of fragments, and the requirements of modern research. In this sense, subjectively realised physical criteria are the least reliable, like colour, shape, the quantity of additives, the clarity of the glaze and polish. Since these criteria are identified without standardised methods (such as colour tables), the data provided is either incomparable or too generalised. Less subjective is data of an interpretational character: the type of utensil, the cultural dependence of a fragment, the ornamental technique and type, deformations, throwing flutes, firing, the condition, signs and symbols, the craftsman and signs of usage. These criteria are reliable if they are employed by experts and professionals. However, very often mostly amateurs (students or helpers) take part in the sorting of material. Therefore, this group of criteria in the characterisation of fragments cannot be reliable. Another type of attribute (type of additives, colouring, thickness of glaze, the technical bonding of the fragment, the decorative technique) can be identified precisely and specified only during special research, so they cannot be applied universally in reports and the characterisation of fragments.

Only 13 physical criteria of fragment remain (size, minimum and maximum thickness, amount of addi- 


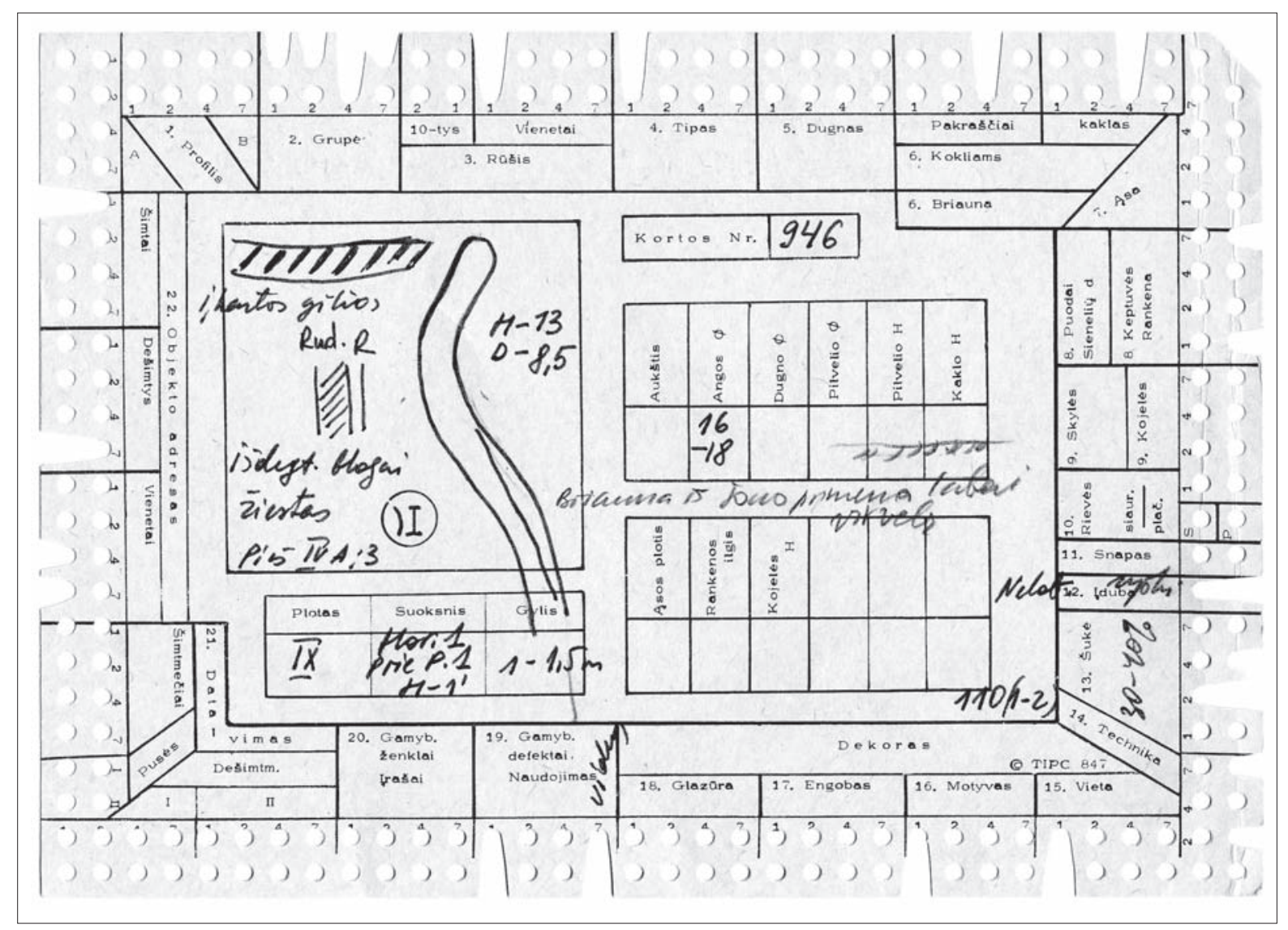

Fig. 5. The ceramic fragment characterisation push-card (after Žulkus personal archive).

tives, group, the glaze and its position, type of utensil part, number, weight and measurements of ornamentation, number of elements, position and diameter). They can be precisely identified and described. There would be no problem whatsoever if a fragment was a complete article. However, it is a fragment of a larger article, which is usually a utensil. How, and to what extent, do these criteria represent the utensil itself? The thickness of fragments and the amount of additives are derivative products in pot manufacturing techniques, and they are linked with methods employed in manufacturing utensils. The latter have already been described, and very often this information becomes redundant. The measurements of the ornamentation, the number and the location of the elements are not typical of each ceramic fragment. Of some types they are not typical at all. Besides, ornamentation is very different, and hardly responds to systematisation (particularly on a wider cultural-chronological scale), their different types possess many more objective physical criteria, and nowadays there are no related parameters which could be treated as important attributes in the characterisation of ceramics itself. Finally, ornamentation in the analysis of types is usually characterised by the descriptive method, providing quantitative and percentage values of them. The glaze-related situation is similar, the presence of which on utensils is sometimes treated as a decorative (ornamental) element.

The size, a physical criterion characterising a fragment, should be discussed separately. When defining objects, their size is naturally an understandable criterion, and measurements of fragments should not surprise. Unfortunately, in this case, attention is not paid to the fact that a fragment is not an article, but a part or an element of a larger article (usually a utensil), and very often it is difficult or even impossible to point to its exact place on it. A ceramic fragment matches fragments of any other article, but fragments of other articles are not numerous, and after a detailed analysis some could be identified as elements of specific articles. In the case of ceramic fragments, it is the opposite: they are abundant, and their further exploration is hardly possible. Only hoards of ceramic fragments are exceptional, but these cases no longer cause any problems (everything is collected and registered as part of a single utensil, aiming at its reconstruction in the future). The size of fragments is closely related to another physical parameter, weight, which in any case is a more universal value. The weight of an intact utensil could always be compared to the weight of a single fragment, and calculations could easily be made about the approximate

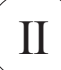

ARCHAEOLOGICAL CERAMICS 
number of fragments that it broke into. Anyway, this number should be known from archaeological explorations. In this case, the specific number of fragments can vary, largely subject to different circumstances (breakage, the spread and survival of fragments, research methodology). For example, it has been noticed that higher-quality utensils break into larger fragments (Valickis 1987, p.29). Therefore, the size of a ceramic fragment is more important for the characterisation of conditions of the cultural layer and its formation rather than for a description of the fragment itself. Generalising sightings and the above-mentioned data are sufficient for their characterisation.

The remaining five physical criteria (group, type of utensil element, flexion diameter, number, weight) remain objective criteria that characterise any ceramic fragments. The ceramic group signifies its major cultural-chronological types (such as brushed ceramics, Kielce ceramics), which are identified in previous explorations and need no further discussion (except the attachment of single fragments to one or another type). The specification of utensil elements is a fairly objective and well-established criterion. On the basis of other cases and their classification, as well as personal experience, fragments of unidentified types should also be distinguished. All disputed fragments should be attributed to this one. Flexion diameter is traditionally estimated by employing the diameter table. Now it can be done in an even more accurate way, by employing other modern measuring techniques. It should be mentioned that diameters can be estimated only for fragments in which they have properly shown up. Usually they are missing in small or modelled fragments (the diameters in the latter are very often irregular). The diameter characterises both the size of the utensil and its shape. The number of fragments needs no comment if the question does not arise about what a fragment is. Ceramic articles manage to break into very small fragments, and their survival is similar to that of the surrounding soil. The question about what a fragment is will be discussed in the next chapter. The weight-related criterion is also absolutely obvious: it is expressed in grams, by weighing the fragments without dirt.

The problem of numbers is exceptional in the minimal characterisation of discovered ceramics on the report level. This determines the expenditure of field explorations, the analysis of excavated material, the level and profundity of object knowledge, and the opportunities for the storage of collected ceramics. In practice, these problems require a response to specific questions: whether to collect everything or not, to register everything or not, to keep everything or not.
The quantity of collected material on field trips is determined by the research methodology employed. Different numbers of fragments will be discovered if the found cultural level is spaded (as was common practice in the first half of the 20th century), or if the soil is screened, which makes it possible under favourable conditions to collect almost all finds (Zabiela 1998b, p.526). The Velikuškès hill-fort (near Zarasai, eastern Lithuania) is an example of the first option. In 1933, a total area of 1,564 square metres was explored around this hill-fort and settlement from the first millennium $\mathrm{BC}$ to the 13th century. A total of 1,115 fragments were found (Zabiela 1994, p.47ff). This makes about two fragments to three square metres, though ceramics are abundant in hill-forts that belonged to the culture of brushed ceramics. In 2001, the exploration of Laužiškis hill-fort (near Širvintos, east Lithuania) resulted in the discovery of 412 pot fragments in a 30-centimetre cultural layer and an area of 31 square metres (299 registered, and 113 small selected ones) (area 2), which is about 13 to a square metre (Zabiela 2001, pp.13, 19, 49-50). The second option was employed in the exploration of Šeimyniškèliai hill-fort (near Anykščiai, east Lithuania). Since 1996, when the screening of cultural layers started, small fragments have also continuously been traced. In 1996 alone, 100 tiny fragments (up to three square centimetres), weighing 432 grams in total (Zabiela 1998a, p.117), were discovered. Another 34 were found after screening a previously explored area of 13 square metres in area 14 (Zabiela 1998a, p.115). In the process of exploration, 603 fragments (386 registered, and 217 small selected ones) were found in an area of 100 square metres (Zabiela 1995, p.61ff). The recalculation of unnoticed fragments in the cultural layer of the entire area by means of pallet and scrape resulted in the discovery of another 260 fragments, which means that the employment of traditional methods and the avoidance of screening leads to around $30 \%$ losses. On the other hand, the screening of cultural layers results in at least a $30 \%$ increase in labour consumption. Accordingly, any ceramics-related findings and conclusions should be corrected on a similar principle.

Another problem is related to the primary accounting of discovered ceramics included in reports. Previous examples show that selected non-informative fragments (up to three square centimetres and fragmented lengthways, without a possibility for the identification of shard thickness) make up $37 \%$ to $56 \%$ of all ceramics. Depending on the data employed, the informative percentage of collected material varies in this case from a third to a half. Anyway, the bottom criterion 


\begin{tabular}{|l|l|l|l|l|l|l|l|c|}
\hline A rea & Depth $\mathrm{cm}$ & Quadrate & Object & Group & Type & Diameter cm & Number & Weight g \\
\hline 1 & $0-20$ & $1-2 \mathrm{~A}-\mathrm{B}$ & Pit & B (1-11) & P (3) & $15(3)$ & 2 & 30 \\
\hline 1 & $0-20$ & $1-2$ A-B & Pit & B (1-11) & S (4-8) & $12(40,13(7)$ & 5 & 75 \\
\hline 1 & $0-20$ & $1-2$ A-B & Pit & B (1-11) & D (9-10) & $9(8)$ & 2 & 26 \\
\hline 1 & $0-20$ & $1-2$ A-B & Pit & B (1-11) & N (11) & - & 1 & 3 \\
\hline 1 & $0-20$ & $1-2$ A-B & Pit & L (12-20) & P (12) & - & 1 & 6 \\
\hline
\end{tabular}

B - brushed, L - plain modelled, P - rim, S - wall, D - base, N - unidentified. Inventory numbers are put in columns for groups, types, diameters, numbers and weight.

of their smallness, showing the physical parameters of registered fragments, should be common to all archaeological periods. This could be a fragment of five by five millimetres or similar dimensions, making up less than 0.25 square centimetres of their area. Smaller fragments should be treated as crumbs, which in large numbers could be defined by one single physical weight criterion. Fragments of over 0.25 square centimetres should be registered as separate items.

The conservation of collected materials is a serious problem for museums without sufficient space in repositories to keep them. It will become relevant to researchers when the particular research into this material starts, which is likely to happen in Lithuania in a couple of decades or later, due to the continuously growing disproportion between excavated and published material (particularly relating to ceramics). Registered fragments are gathered in them, but unlisted ones are treated differently (depending on the period and abundance). The different approach to material excavated somewhere, not conserved and kept in museums, may cause additional problems in the future. They are necessary for the employment of already registered fragments in different destructive studies, or vitiation with selected materials from those places in which such ceramics were always missing (such as the discharge of selected fragments into soil, transported to fixed locations). Established archaeological research on construction sites is seriously restricted by the employment of methodological requirements insisting on burying selected materials in the same or another object (Archeologiniu 1994, p.361). Therefore, it is thrown on the scrap heap until the possibilities for its conservation and keeping appear. ${ }^{9}$

The generalisation of problems related to numbers of ceramics leads us to the conclusion that the constantly

\footnotetext{
9 Around 1990, this idea was proposed by Liudvikas Dzikas (1955-1991), head of the Archaeology Department of the Monument Conservation Institute.
}

increasing particularity and minuteness of archaeological studies and the decline of the extant archaeological heritage (it can be explored only once) require the collection and conservation of all ceramics. This approach by museums collecting archaeological finds may lead to them turning into museums of ceramics, though in practice this problem is not so huge. Even a million collected fragments means nothing but thousands of tons of finds that could easily be kept in a single repository corresponding to minimum requirements. Keeping all discovered artefacts (including a large number of eco-facts) would enable us to deal more responsibly with the protection of the archaeological heritage in situ, that is, avoiding unnecessary excavations, as the soil itself is the best and most natural keeper.

After a discussion of objectivity in criteria for the characterisation of ceramics, the choice inevitably has to be made between an individual and a common approach to them. Previously suggested assumptions show that neither of these methods can be very impartial when characterising the ceramics of an explored object. In that case, a more rational way should be chosen. This tells us less about ceramic fragments, but its persistent value is significant. They are tables of a generalising character, making attempts to emphasise more the complete survival of excavated material, rather than its entire placement in reports.

In this way, a table characterising ceramics at a minimum is formed (see example, its filling in is provisional). The remaining abundant and different attributes belong to the sphere of specialised research in ceramics, and overstep the limits of its primary characterisation.

Thus, the basic attention of researchers at the primary (report level) stage of work with ceramics is directed towards the analysis of fragment groups rather than towards one single fragment. This level is compulsory for everyone. Other important criteria that are indefin-



ARCHAEOLOGICAL CERAMICS 
able in archaeological literature (such as rim profile and ornamentation) should be presented in reports in the form of scale pictures or references to corresponding catalogues (when they are ready), and supported by inventory numbers. The introduction of such pictures is without restrictions and limitations (reports can be illustrated with pictures of all discovered fragments), if researchers find it necessary. In the next few years, developing 3D technologies will replace these illustrations with electronic 3D images. Their processing, presentation and employment is another thing.

A ceramic fragment, a mass archaeological find already in the primary stage of work, requires (with the planning of the report) strict standardisation and the employment of unified criteria. In the modern democratic archaeological community, this can only be achieved by invoking satisfactory arguments and persuasive examples, and discussing the optimal relationship between attempts and the results achieved. Accordingly, the suggestions of this article should be treated as a further continuation of the discussion which started among archaeologists a long time ago and continued during the conference 'Research into Urban Culture in the Middle Ages and Modern Times (on the Basis of Archaeological Data)' held in Klaipeda on 12 and 13 November 2009.

\section{Conclusions}

Ceramic fragments seem to be the most numerous excavated archaeological material found in many archaeological sites, starting from the end of the sixth millennium BC. The primary processing of these fragments is problematic for reports on archaeological research. These problems built up during the previous period of archaeological development, and now they prevent the proper employment of these reports in further explorations as a primary source. All of this preconditions the very poor interest of Lithuanian archaeologists in ceramics, and the low level of its research (see annex, bibliography of studies on archaeological ceramics-related topics before 2012).

Excavated ceramic fragments only attracted the fuller attention of researchers at the end of the 19th century. Until the 1980s, written descriptions of ceramics prevailed in reports about archaeological research. At the beginning of the 1980 s, the description of ceramics by means of tables started at the Monument Conservation Institute. Up to now, both methods of description are employed.

The above-mentioned table is a more progressive form of description, more standardised, concentrating information, and saving space in reports. The different attributes in the characterisation of ceramic fragments (up to 36 at present) are considered an essential failing of these tables.

Five physical criteria in the description of ceramic fragments are their basic attributes (group, type of utensil part, diameter, number, weight). On that basis, a description table of archaeological ceramics has been developed (see example), and is the minimum of primary processing presented in reports on archaeological research.

Utensil fragments of over 0.25 square centimetres are treated as separate items. They are registered and given up for conservation. This is the material background for further detailed research into ceramics.

\section{Abbreviations}

ATL - Archeologiniai tyrinèjimai Lietuvoje ... metais. Vilnius (since 1967-)

LA - Lietuvos archeologija. Vilnius (since 1979-).

LIM - Lietuvos istorijos metraštis. Vilnius (since 1971-).

MAD'A - Lietuvos TSR Mokslu akademijos darbai. A serija, Vilnius (1955-1989).

LII R - Lithuanian Institute of History, Archive.

\section{References}

\section{Manuscripts}

BEŠĖNIENĖ, D., 1976. Vilniaus senamiesčio 26 kvartalo (Giedrio 8) archeologiniu tyrimu ataskaita (unpublished excavations report). In: LII R, f. 1, No. 526.

KULIKAUSKAS， P., KULIKAUSKIENE R., 1956. Nemenčinès piliak. (Vilniaus raj.) $1952 \mathrm{~m}$. tyrinejjimu radinių sąrašas (unpublished finds list). In: LII R, f. 1, No. 110

KULIKAUSKIENĖ, R., 1977. Narkūnai, Utenos raj., 1976 m. Utenio piliakalnio (Didžiojo) tyrinèjimai (unpublished excavations report). In: LII R, f. 1, No. 672.

LEGAITĖ-SKARDŽIUVIENĖ, R., 1967. Vilniaus senamiestyje žvalgybinio pobūdžio archeologiniai tyrimai 1959 1967 m. (unpublished excavations report). In: LII R, f. 1, No. 3276 .

MARKELEVIČIUS， J., 1973. Merkinès senamiesčio kultūrinio sluoksnio fiksacijos darbų ataskaita. $1973 \mathrm{~m}$ rugsėjo 19 - rugsèjo 20 d. (unpublished excavations report). In: LIIR, f. 1, No. 380.

TAUTAVIČIUS, A., 1956. LTSR MA Istorijos instituto vykdytu archeologiniu kasinèjimu Vilniuje Gedimino kalno šiaurinejje papédejje 1956.V.14 - X.3 dienoraštis (unpublished excavations report). In: LIIR, f. 1, No. 39.

UŠINSKAS, V., 1983. 1983 m. archeologinių tyrinèjimų Vilniuje, K. Giedrio g. 8 ataskaita, 4(1). Buitinès keramikos radinių sąrašas (unpublished excavations report). In: LII R, f. 1, No. 1394

ZABIELA, G., 1995. Anykščių rajono 1995 m. archeologinès ekspedicijos ataskaita (unpublished excavations report). In: LIIR, f. 1, No. 2505. 
ZABIELA, G., 2001. Laužiškio piliakalnio (Širvintų raj., Zibalų seniūn.) 2001 metų archeologinių tyrinèjimu ataskaita (unpublished excavations report). In: LIIR, f. 1, No. 3744.

ŽALNIERIUS, A., 1975. Kauno senamiestis. Rotušès a. Nr.2-3. Archeologiniai tyrimai (unpublished excavations report). In: LIIR, f. 1, No.482.

ŽALNIERIUS, A., VAŠKELIS, A., RIDIKAITĖ, V., BALČIŪNAS, D., BERTAŠIUS, M., BUTKUS, V., JUCHNEVIČIUS, A., 1984. Kauno senamiestis. Archeologiniu tyrimų ir priežiūros ataskaitos nuo 1962 iki 1974 m. Rotušès rūsiai. Rotušès aikšte. 1966-1973 m. rastų archeologinių radinių sąrašas (unpublished excavations report and list of find artefacts). In: LII R, LIIR, f 1, No. 1118.

ŽULKUS, V, 1981a. Klaipėdos m. keramika iki XIX amžiaus. T.1. $1980 \mathrm{~m}$. darbo ataskaita (unpublished excavations report). In: LIIR, f. 1, No. 906.

ŽULKUS, V, 1981c. Klaipedos piliavietè. 1979 ir 1980 m. archeologinių tyrimų ataskaita. T. 1. In: LIIR, f. 1, No. 873

\section{Literature}

ARCHEOLOGINIŲ, 1994. Archeologinių tyrinejimų ir atsiskaitymo už juos bendrieji reikalavimai. In: Archeologiniai tyrinejimai Lietuvoje 1992 ir 1993 metais. Vilnius: leidykla Diemedis, 354-366.

DÖRING, J., 1882. Der Burgberg in Kommodern und der Pilskaln an der Tatola, nebst Notizen über Ratten und Terwetten. In: Sitzungsberichte der Kurländischen Gesellschaft für Literatur und Kunst in Mitau. Mitau, 37-41.

GIRININKAS, A., 2009. Akmens amžius. In: Lietuvos archeologija, I. Vilnius: Versus aureus.

HOŁUBOWICZ, W., 1950. Garncarstwo wiejskie zachodnich terenów Białorusi. Toruń: Nakładem Towarzystwa Naukowego.

KLAIPĖDOS, 2010. Klaipédos pilies ir senamiesčio buitine keramika XIV a. vid. - XIX a. iš Mažosios Lietuvos is torijos muziejaus rinkiniu. Compilers R. Songailaite, L. Rutkaitienè. Klaipéda: Mažosios Lietuvos istorijos muziejus.

KRZYWICKI, L., 1917. Grodziska górno - litewskie. Grodzisko na Górze Ościkowej pod Rakiszkami. In: Pamiętnik fizyograficzny, XXIV/V, 1-42.

KULIKAUSKAS, P., LUCHTANAS, A., 1980. Vilniaus miesto archeologinès komisijos ikūrimas ir veikla 19111914 metais. In: Lietuvos TSR aukštuju mokyklu mokslo darbai. Istorija, 20 (1), 97-109.

PUZINAS, J., 1938. Naujausiu proistoriniu tyrimu duomenys (1919-1938 metu Lietuvos proistoriniu tyrinejimu apžvalga. In: Senove, 4. Kaunas, 175-303.

RIMANTIENĖ, R., 1989. Nida. Senuju baltu gyvenvietè. Vilnius: Mokslas.

TARASENKA, P., 1924. Gimtoji senovè (ieškojimas, pažinimas ir apsangojimas). Šiauliai: „Kultūros“ bendrovè.

TAUTAVIČIUS, A., 2000. Lietuvos archeologijos bibliografija 1782-1998. Vilnius: „Lietuvos pilys“.

UŠINSKAS, V. 1984. Tyrinëjimai Vilniuje, K. Giedrio gatveje. In: ATL 1982 ir 1983 metais. Vilnius: Lietuvos istorijos institutas, 118-121.

VAITKIAVICHIUS, G., KATALINAS, K., USHINSKAS, V. 1985. Opyt formalizirovanogo opisaniia massovykh arkheologicheskikh nakhodok. In: V.V. SEDOV, ed
Arkheologiia i istorija Pskova i pskovskoi zemli. Pskov, 5-7.

VALATKA, V., 1974. Renavo (Mažeikiu raj.) piliakalnis. In: Archeologiniai ir etnografiniai tyrinejimai Lietuvoje 1972 ir 1973 metais. Vilnius, 14-15.

VALICKIS, V., 1987. XVII a. I pusès keramikos rinkinys iš Kaltanėnų. In: A. BE்KŠTA, compiler. Jaunuju muziejininku konferencijos "Muziejai ir ju kolekcijos" pranešimu tezès. Vilnius, 29-31.

VOLKAITÉ-KULIKAUSKIENĖ， R., $1986 . \quad$ Narkūnų Didžiojo piliakalnio tyrinejimų rezultatai) (Apatinis kultūrinis sluoksnis). LA, 5, 5-49.

WILCZYŃSKI, F., 1836. Wędrówka do gór Utenesa, xiążęcia Litwy zalożyciela Uciany. Tygodnik Petersburski, 93, 559-560.

ZABIELA, G., 1987. Keramikos fragmentu kolekcijos aprašymo pagrindai. In: A. BE்KŠTA, compiler. Jaunuju muziejininku konferencijos "Muziejai ir ju kolekcijos" pranešimu tezès. Vilnius, 32-34.

ZABIELA, G., 1994. Velikuškių piliakalnio "kapai”. In: A. GIRININKAS, ed. Gyvenviečiu ir keramikos raida baltu žemèse. Vilnius: Savastis, 46-60.

ZABIELA, G., 1998a. Šeimyniškèlių piliakalnio tyrinèjimai 1996 ir 1997 metais. In: ATL 1996 ir 1997 metais. Vilnius: Lietuvos istorijos institutas, 115-119.

ZABIELA, G., 1998b. Grunto sijojimas archeologiniuose kasinejimuose. In: ATL 1996 ir 1997 metais. Vilnius: Lietuvos istorijos institutas, 525-527.

ZABIELA, G., 2010. Archeologinès keramikos apžvalga. Radiniai Utenos krašte. In: V. NAVIKIENĖ, ed. Keramika Utenos krašte Kaunas: Arx Baltica, 27-43.

ZHOGAS, I,. 1900. Arkheologicheskiia zametki po Telshevskomu uezdu. In: K. GUKOVSKIJ, compiler. Pamiatnaia knizhka Kovenskoi gubernii na 1901 god. Kovno, 33-49.

ŽULKUS, V., 1981b. XVI-XIX a. Klaipedos buitinès keramikos klasifikacija. In: I. JUČIENĖ, ed. Archeologiniai tyrimai Lietuvos miesty istoriniuose centruose. Vilnius, 38-39, 86-87.

ŽULKUS, V., 1997. Palangos viduramžiu gyvenvietès. Acta Historica Universitatis Klaipedensis, VI.

ŽULKUS, V., 2007. Palanga in the Middle Ages. Ancient settlements. Vilnius: Versus aureus.

\section{APPENDIX 1. BIBLIOGRAPHY \\ OF LITHUANIAN ARCHAEOLOGICAL \\ POTTERY}

\section{5}

1. MULEVIČIENĖ, I., 1965. Lietuvos X-XVI amžių kapinynų keramika. $M A D^{\prime} A, 1(2), 41-58$.

\section{6}

2. DAUGUDIS, V., 1966. Nekotorye dannye o khronologii i proiskhozhdenii keramiki s sherokhovatoi poverkhnost'iu v Litve. In: Drevnosti Belorusii. Minsk,163-165.

3. DAUGUDIS, V., 1966. O nakhodkakh setchatoi keramiki v Litve. In: Pronksiajast varase feodalismini. Tallinn, 3841.

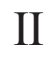

ARCHAEO-

OGICAL CERAMICS 
4. DANILAITĖ, E., 1966. Ankstyvosios brūkšniuotosios keramikos kilmès klausimu. MAD'A, 2, 111-125.

1967

5. DANILAITĖ, E., 1967. Brūkšniuotoji keramika Lietuvoje. In: Spalio revoliucija ir visuomeniniai mokslai Lietuvoje. Vilnius, 229-231.

6. DANILAITĖ, E., 1967. Brūkšniuotosios keramikos išnykimo Lietuvoje klausimu. $M A D^{\prime}$ 'A, 1, 35-50.

7. DANILAITĖ, E., 1967. Shtrikhovannaia keramika v Litve (nekotorye dannye po voprosam ob etnogeneze litovtsev). Avtoreferat kandidatskoi dissertatsii. Vil'nius.

\section{8}

8. DANILAITĖ, E., 1968. Lietuvos brūkšniuotosios keramikos ornamentas. $M A D^{\prime}$ 'A, 1, 41-57.

1971

9. RUŠAITE, E., 1971. Keramika gorodishch iugo-zapadnoi chasti Litvy (po dannym issledovannykh gorodishch v mestnostiakh Kaukai i Obelite Alitusskogo rajona). In: Tezicy III-ei regional'noi studencheskoi arkheologoetnograficheskoi konferentsii vuzov severo-zapada SSSR. Riga, 53-54.

1980

10. GIRININKAS, A., 1980. Keramikos ornamentikos ypatumai rytų Lietuvoje (pagal virvelinès ir Narvos kultūru keramiką). In: Jaunuju istoriku darbai, 3. Vilnius, 94-96.

11. ŽULKUS, V., 1980. Klaipėdos senamiesčio archeologiniu tyrimų metu rastos keramikos analizès išvados. In: Istorijos ir kultūros paminklu tyrimai ir restauravimas Lietuvos TSR, 1976-1980. Vilnius, 34, 113, 174-175.

\section{1}

12. JANKAUSKAS, A., 1981. Lietuvos TSR senamiesčių statybine keramika. In: Archeologiniai tyrimai Lietuvos miestu istoriniuose centruose. Vilnius, 45-46, 93-94.

13. VAITKEVIČIUS, G., 1981. XV-XVII a. buitinès keramikos importas Vilniuje. In: Archeologiniai tyrimai Lietuvos miestu istoriniuose centruose. Vilnius, 40-41, 88-89.

14. ŽULKUS, V., 1981. XVI-XIX a. Klaipèdos buitinès keramikos klasifikacija. In: Archeologiniai tyrimai Lietuvos miestu istoriniuose centruose. Vilnius, 38-39, 86-87.

1982

15. GIRININKAS, A., 1982. Razlichiia keramiki razvitogo neolita v vostochnoi i zapadnoi v Litve. In: Drevnosti Belorusii. Minsk, 19-27.

16. KUNCIENĖ, O., 1983. Grigiškių (Neravų, Trakų raj.) pilkapyno radiniai (3. Keramika). MAD'A, 2, 50-60.

17. MIKAILA, V., VAITKEVIČIUS, G., 1983. Kai kurie Vilniaus XVI-XVII a. raudono molio plonasienès keramikos tyrimai. In: Archeologinès ir numizmatinès medžiagos komplektavimas ir konservavimas. Vilnius, 3840.

18. VAITKEVIČIUS, G., 1982. Baltosios keramikos importas Vilniuje XIV-XVII a.. In: Jaunujų istoriku darbai, 4.Vilnius, 95-97.

\section{4}

19. MIKAILA, V., VAITKEVIČIUS, G., 1984. Kai kurie duomenys apie importinę Kelcų keramiką Vilniuje. LIM, 1983, 5-16.

20. MIKAILA, V., SELIVANOVA, N.B., VAITKIAVIČIUS, G., 1984. Issledovaniia bytovoi keramiki Vil'niusa XIVXVII vv. In: Komleksnye metody $v$ izuchenii istorini $s$ drevneishikh vremen do nashikh dnei. Moskva, 72-73.

\section{5}

21. VAITKIAVICHIUS, G., KATALINAS, K., USHINSKAS, V. 1985. Opyt formalizirovanogo opisaniia massovykh arkheologicheskikh nakhodok. In: Arkheologiia i istorija Pskova i pskovskoi zemli. Pskov, 5-7.

1987

22. MERKEVIČIUS, A., 1987. Stanaičių kapinyno keramika. In: Jaunuju istoriku darbai, 6. Vilnius, 85-87.

23. VALICKIS, V., 1987. XVII a. I pusès keramikos rinkinys iš Kaltanènų. In: Jaunuju muziejininku konferencijos "Muziejai ir ju kolekcijos" pranešimu tezès. Vilnius, 2931.

24. ZABIELA, G., 1987. Keramikos fragmentų kolekcijos aprašymo pagrindai. In: Jaunuju muziejininku konferencijos "Muziejai ir ju kolekcijos" pranešimu tezès. Vilnius, 32-34.

1988

25. GIRININKAS, A., 1988. Brūkšniuotosios keramikos formavimasis Rytu Lietuvoje. In: Aktualūs kultūros paminkly tyrinėjimu uždaviniai. Vilnius, 16-25.

1989

26. Grigalavičienè, E., Brūkšniuotosios keramikos lokaliniai variantai Lietuvoje. MAD'A, 3, 69-83.

1990

27. VAITKEVIČIUS, G., 1990. Mesbauerio spektroskopijos (MS) pritaikymas archeologinès keramikos tyrimuose, būdų paieškos ir pagrindimas. In: Paminklotvarkos darbai ir problemos. Vilnius, 68-69.

\section{2}

28. DAUGUDIS, V., 1992. O rannei shtrikhovannoi keramike v Litve. In: Arkheologiia i istorija Pskova i pskovskoi zemli. Pskov, 93-94. 
1993

29. BERTAŠIUS, M., 1993. Kauno vėlyvųų viduramžių keramika. Architektūros paminklai, 13, 13-18.

1994

30. GIRININKAS, A., 1994. Ornamentas - genties požymis. In: Ornamentikos raida Rytu Lietuvoje. Pranešimu santrauka. Vilnius, 8-9.

31. JUODAGALVIS, V., 1994. Kiaurasienès keramikos klausimu. Kultūros paminklai, 1, 4-5.

32. JUODAGALVIS, V., 1994. Užnemunès neolito keramika. In: A. GIRININKAS, ed. Gyvenviečiu ir keramikos raida baltų žemèse. Vilnius: Savastis, 148-152.

1996

33. POŠKIENĖ, J., 1996. Senųjų Trakų XIV a. keramika. LIM, 1995, 15-28

1999

34. JASIUKEVIČIUS, V., VAITKEVIČIUS, G., 1999. XVII a. kalkinio fajanso, rasto Vilniuje, tyrimai. $L A, 18,271$ 282

35. POŠKIENĖ, J., 1999. Senųų Trakų pilies, senovès gyvenvietes ir benediktinų vienuolyno buitinè keramika (XIV a. - XVII a. pirmoji pusè). LIM, 1998, 5-23.

36. VAITKEVIČIUS, G., 1999. Vilniaus buitine keramika (XIV-XVII a.). Daktaro disertacijos santrauka. Vilnius.

2000

37. GRINEVIČIŪTĖ, G. 2000. Virvelinė keramika Pietų Lietuvoje. $L A, 19,109-124$.

38. IRŠĖNAS, M., BUTRIMAS, A., 2000. Daktariškès 5-osios gyvenvietès keramikos su organinès kilmès priemaišomis ornamentika. $L A, 19,125-138$.

\section{2}

39. BRAZAITIS, DŽ., 2002. Narviškos keramikos stiliai Rytų Lietuvoje. LA, 23, 51-72.

40. POŠKIENĖ, J., Traku piliu ir miesto viduramžiu keramika (XIV a. - XVI a. I pusé). Daktaro disertacijos santrauka. Vilnius.

2004

41. BUTRIMAS, A., OSTRAUSKIENĖ, D., 2004. Biržulio apyežerio neolito gyvenviečių virvelinè keramika Vilniaus dailès akademijos darbai. Kultūrinio lanď̌afto raida žemaičiu aukštumoje, 34,121-144.

42. KAZAKEVIČIUS, V., 2004. Kalniškių V-VI a. kapinyno keramika. $L A, 26,9-28$.

43. POŠKIENĖ, J., 2004. Trakų pilių ir miesto viduramžių keramika. In: Miestu praeitis, 1. Vilnius, 125-173.
44. VAITKEVIČIUS, G., 2004. Puodininkystès profesionalizacija XIV-XVII a. Vilniuje. In: Miesty praeitis, 1. Vilnius, 175-276.

\section{5}

45. BLIUJIENĖ, A., 2005. Baltų palaidojimo indai, arba kad dūšia nejaustų troškulio. $L A, 28,81-96$.

46. BLIUJIENĖ, A., 2005. Pottery in Curonian Cremation Burials. Some Aspects of Interaction across the Baltic Sea in the Late Viking Age and Early Medieval Period. In: V. LANG, ed. Interarchaeologia 1. Culture and Material Culture. Papers from the first seminar of the Baltic archeaologists (BASE), held at the University of Tartu, Estonia, October 17th-19th, 2003. Tartu-Riga-Vilnius, 147-166.

47. VENGALIS, R., 2007. Grublètoji keramika Rytu Lietuvoje. $L A, 32,105-132$.

2008

48. VENGALIS, R., 2008. Rytų Lietuvos keramika VIII-XII a.. $L A, 33,41-70$.

\section{0}

49. KLAIPĖDOS PILIES ir senamiesčio buitinė keramika XIV a. vid. - XIX a. Klaipėda: Mažosios Lietuvos istorijos muziejus, 2010.

II

ARCHAEOLOGICAL CERAMICS

Received: 20 October 2011; Revised: 11 November 2011; Accepted: 20 December 2011.

Gintautas Zabiela

Klaipeda University Institute of Baltic Sea Region

History and Archaeology

Herkaus Manto St 84

LT-92294 Klaipeda, Lithuania

E-mail: gzabiela@gmail.com

\section{ARCHEOLOGINE KERAMIKA \\ LIETUVOJE: PIRMINIO \\ APDOROJIMO ASPEKTAS}

\section{GINTAUTAS ZABIELA}

\section{Santrauka}

Keramikos šukès yra gausiausias tiek Lietuvos, tiek ir daugelio kitų šalių archeologinis radinys. Iš VI tūkstantmečio pr. Kr. - XX a. laikotarpio jų sukaupta mažiausiai milijonas vienetų. Tačiau archeologinių tyrimų ataskaitose jos apibūdinamos labai skirtingai. Keramikos šukiu pirminis apdorojimas archeologinių tyrimų ataskaitose šiandien kelia daug problemų. Jos susikaupé per visą ankstesnị archeologijos raidos 
laikotarpi ir trukdo šias ataskaitas kaip pirminị šaltinị tinkamai panaudoti būsimuose tyrimuose. Tokia padètis lèmé labai nedidelị Lietuvos archeologų domejjimąsi keramika ir menką jos tyrimų lygi (žr. priedą - iki 2012 m. pasirodžiusių darbų archeologinès keramikos tema bibliografiją). Paskiros labai detalios keramikos studijos platesnio pobūdžio apibendrinimuose (pvz., V. Žulkaus darbas apie Palangos senąsias gyvenvietes) padèties apskritai nekeičia.

Nors su keramikos liekanomis susidūrè jau pirmieji Lietuvos archeologinio paveldo tyrinètojai, iškasamos keramikos šukès detalesnio tyrinètojų dėmesio nusipelnè tik nuo XIX a. pabaigos. Tik nuo XX a. 8-ojo dešimtmečio pradèta visuotinai rinkti keramikos šukes. Iki pat XX a. 9-ojo dešimtmečio pradžios archeologinių tyrimų ataskaitose vyravo tekstinis keramikos šukių aprašymas. XX a. 9-ojo dešimtmečio pradžioje tuometiniame Paminklų konservavimo institute susiformuoja keramikos aprašymas lentelèmis (1, 3 pav.), bandoma formalizuoti jos pakraštėlių aprašymą (2 pav.). Paskirų bandymų formalizuoti keramikos aprašymus būta ir daugiau (4, 5 pav.). XX a. paskutiniame dešimtmetyje keramikos šukių aprašymuose pradètas nurodyti jos svoris, naudojant skersmenų lentelę, dažniau nustatomi indo angos ir dugno skersmenys. Tiek tekstinis, tiek lentelių keramikos šukių aprašymo būdai naudojami iki šiol.

Keramikos aprašymo lentelès apskritai yra pažangesnė keramikos aprašymo forma, labiau standartizuota, koncentruojanti informaciją ir taupanti vietą ataskaitoje. Pagrindinis lentelių trūkumas iki šiol yra kiekvieno tyrinètojo naudojami skirtingi keramikos šukių apibūdinimo požymiai, kurių, peržiūrèjus ịvairias naudojamų lentelių formas, galima suskaičiuoti net 36 . Tai spalva (išorès, vidaus, masès), dydis, storis (minimalus, maksimalus), forma (pakraštèlio, dugno), priemaišos (rūšis, dydis, gausumas), grupè, glazūra (spalva, vieta, skaidrumas, blizgesys, storis), dažai, rūšis (indo, indo dalies, technologinè, kultūrinè), skaičius, svoris, ornamentas (technika, rūšis, matmenys, elementų kiekis, vieta), skersmuo, deformacijos, žiedimo rievès, išdegimas, būklè, ženklai, naudojimo žymès. Juos suskaidžius dar smulkiau ir pridejjus archeologinès radinio metrikos grafas, sukurta ir naudota net 104 grafų keramikos aprašymo lentele, kuri vis vien neatskleidžia visos keramikos ịvairovès, yra nepraktiška ir ilgai pildoma.

Iš pirminio apdorojimo etape naudojamų minètų $36 \mathrm{ke}-$ ramikos šukès požymių išskirti 5 esminiai jos fiziniai kriterijai (keramikos grupe, indo dalies rūšis, skersmuo, skaičius, svoris). Šių kriterijų apibūdinimas yra mažiausiai subjektyvus. Jų pagrindu sudaryta archeologinès keramikos aprašymo lentele (žr. jos pavyzdị) yra archeologinių tyrimų ataskaitose pateikiamo pirminio keramikos apdorojimo minimumas.

Tam tikrą problemą kelia keramikos šukès dydis, kuris smarkiai ịvairuoja priklausomai nuo ịvairių indo dužimo, tolesnio šukių pasklidimo, išlikimo sąlygų ir pačios tyrimų metodikos. Šukių dydis lemia ir jų skaičių. Atskira keramikos šuke laikomi didesni nei $0,25 \mathrm{~cm}^{2}$ indo fragmentai. Jie visi inventorinami ir perduodami saugoti. Tai būsimų detalesnių keramikos tyrimų materialinè bazè. Mažesni keramikos fragmentai atskirai neapskaitomi.

Archeologinių tyrimų ataskaitos lygyje pagrindinis tyrinètojo dèmesys turi būti kreipiamas nuo darbo su atskira šuke ị darbą su šukių grupèmis. Šis lygis tampa privalomas visiems. Kitus lentelèje neapibūdintus archeologinèje literatūroje svarbiais laikomus kriterijus (pvz., briaunos profilis, ornamentas) ataskaitose tikslinga pateikti mastelinio vaizdo forma (ateityje naudojant 3D vaizdą) arba nuorodomis i atitinkamus katalogus. Igyvendinus šiuos principus, archeologinès keramikos pažinimas žengtų i kokybiškai naują etapą. 